\title{
Type II Citrullinemia in an Elderly Patient Treated with Living Related Partial Liver Transplantation
}

\author{
Kiyoyuki Takenaka, Ichiro Yasuda, Hiroshi Araki, Tomoo Naito, Yasushi Fukutomi, Hiroo Ohnishi, \\ Noriyoshi Yamakita*, Takeshi Hasegawa*, Hirohide SATO*, Yasunobu Shimizu*, \\ Hidetoshi MatsunAmi* and Hisataka MoriwaKI
}

\begin{abstract}
A 60-year-old woman was admitted to our hospital for repeated consciousness disturbance. Blood examination showed hyperammonemia, and plasma amino acid analysis revealed a marked increase in the citrulline level. To establish a diagnosis, a percutaneous needle biopsy of the liver was performed. The determination of the urea cycle enzyme activities revealed a selective marked decrease in argininosuccinate synthetase activity, indicating the final diagnosis of type II citrullinemia. The mean survival period of this disease after the appearance of symptoms has been reported as 26.4 months, and most conservative treatments are not effective. We performed a living related partial liver transplantation. Over the subsequent 13-month follow-up, the patient's condition has remained fairly good. (Internal Medicine 39: 553-558, 2000)
\end{abstract}

Key words: consciousness disturbance, hyperammonemia, argininosuccinate synthetase.

\section{Introduction}

Citrullinemia is an autosomal recessive disease caused by a deficiency of argininosuccinate synthetase (ASS). ASS is the rate-limiting enzyme of the urea cycle, and a deficiency of ASS causes hyperammonemia. Citrullinemia is classified into three types according to the enzyme abnormality and into two forms according to the pathogenesis (1-4). The classical form includes neonatal/infantile onset types I and III. In these cases, the enzyme defect is found in all tissues in which ASS is expressed. The other form is adult-onset, type II citrullinemia with a liverspecific ASS deficiency. It occurs in association with decreased ASS protein with normal kinetic properties in the liver but normal ASS levels in other tissues such as kidney, brain, and skin fibroblasts (2). This type has been mostly found in Japanese patients (5-43), and it is characterized by the sudden appearance of consciousness disturbance, restlessness, and abnormal behavior. Since most conservative treatments are not effective, the prognosis is very poor. However, brain dead (27, $40)$ and living related $(37,42,43)$ liver transplantations have recently been performed in several patients, and have resulted in the elimination of the metabolic abnormalities, such as hyperammonemia and citrullinemia, and the improvement of clinical symptoms. We report a case of a 60 -year-old woman with type II citrullinemia who underwent a living related partial liver transplantation (LRLT). We also review the pertinent Japanese literature.

\section{Case Report}

A 60-year-old woman was first admitted to a hospital because of consciousness disturbance in May 1998. She had been healthy until 1997, but thereafter experienced 6 months of restlessness during the day and insomnia at night. She was given a conservative treatment of rest and drip infusions, and the disturbance improved in several days. However, similar symptoms reappeared 3 times in the next 3 months and became more and more serious. On the 4th admission, hyperammonemia was found, but no other liver dysfunction or any abnormalities of the liver imaging were observed.

She was transferred to our hospital for further examination on August 19, 1998. On admission, she was alert and intelligent, but she found it difficult to answer complicated questions and to solve mental calculations. Neurologically, she was almost normal except for a slight hyperreflexia of all extremities. Blood examinations revealed hyperammonemia (193 $\mu \mathrm{g} /$ $\mathrm{dl}$; normal, 25-70), but normal levels of asparate aminotransferase (15 IU/l; normal, 7-30), alanine aminotransferase (20 IU/l; normal, 7-35), $\gamma$-glutamyl transpeptidase (20 IU/l; normal, 0-70), alkaline phosphatase (219 IU/l; normal, 80-300), and total bilirubin $(0.6 \mathrm{mg} / \mathrm{dl}$; normal, $0.1-1.0)$. The serum to-

From the First Department of Internal Medicine, Gifu University School of Medicine and *Matsunami General Hospital, Gifu

Received for publication July 7, 1999; Accepted for publication January 28, 2000

Reprint requests should be addressed to Dr. Ichiro Yasuda, the First Department of Internal Medicine, Gifu University School of Medicine, 40 Tsukasa-machi, Gifu 500-8705 
tal protein and albumin levels were low (total protein, $5.9 \mathrm{~g} / \mathrm{dl}$; normal, 6.0-8.0; albumin, $2.8 \mathrm{~g} / \mathrm{dl}$; normal, 3.9-4.9). The complete blood cell count, erythrocyte sedimentation rate, and serum $\mathrm{C}$-reactive protein level were normal. No autoantibodies were detected. Although carcinoembryonic antigen (CEA) and $\alpha$-fetoprotein levels were normal, the pancreatic secretory trypsin inhibitor (PSTI) level was increased $(20 \mathrm{ng} / \mathrm{ml}$; normal, 4.6-12.2). Serological tests for hepatitis B and C viruses were negative. Plasma amino acid analysis revealed a marked increase in citrulline $(463.2 \mathrm{nmol} / \mathrm{ml}$; normal, $17-43)$ and a slight increase in arginine $(159.5 \mathrm{nmol} / \mathrm{ml}$; normal, 54-130).

Abdominal ultrasonography (US) revealed a bright liver, and computed tomography (CT) demonstrated diffuse low density in the liver (Fig. 1), findings which were compatible with the diagnosis of fatty liver. Magnetic resonance imaging (MRI) of the brain showed no abnormalities. An electroencephalogram (EEG) showed diffuse slow waves.

Given these results, we diagnosed the patient with citrullinemia. To further establish the diagnosis, a percutaneous needle biopsy of the liver was performed. Microscopic examination of the biopsied tissue showed steatosis; i.e., over $70 \%$ of the liver cells contained small to medium sized fat vacuoles in the cytoplasm, but fibrosis and inflammation were absent (Fig. 2). The urea cycle enzyme activities were measured in the biopsy specimen, and a selective marked decrease in ASS activity was revealed (Table 1). The final diagnosis was type II citrullinemia.

The patient's neurological symptoms were well controlled by a restricted oral protein intake, infusion of branched-chain amino acids, and oral administrations of lactulose and polymixin B sulfate (Fig. 3). Based on our previous reports (see Discussion), however, the prognosis was predicted to be poor. After informed consent was obtained from both the patient and her family, we planned an LRLT using a graft obtained from the patient's healthy 34-year-old son. We also obtained the donor's informed consent to perform a liver biopsy and other preoperative examinations. His ASS activity was confirmed to be almost normal (Table 1) based on the preoperative biopsy of the liver. Approval was obtained from the local ethics committee, and the LRLT was carried out at Matsunami General Hospital on September 22, 1998. The patient's whole liver (volume, $974 \mathrm{ml}$ ) was removed, and the left lobe taken from the donor (volume, $490 \mathrm{ml}$ ) was transplanted.

Both the patient and the donor recovered without complications. After transplantation, the patient began to receive immunosuppression therapy using FK-506, azathiopurine and prednisolone. Plasma levels of ammonia and citrulline were normalized immediately after transplantation, and her neurological symptoms disappeared. The patient was discharged from the hospital on the 46th day after transplantation, and is now being followed up as an outpatient. Over the now 13-month post-surgical follow-up, her condition has remained fairly good, although she has been readmitted twice, each time for several days, due to mild acute rejection in the 3rd and 6th months (Fig. 3).

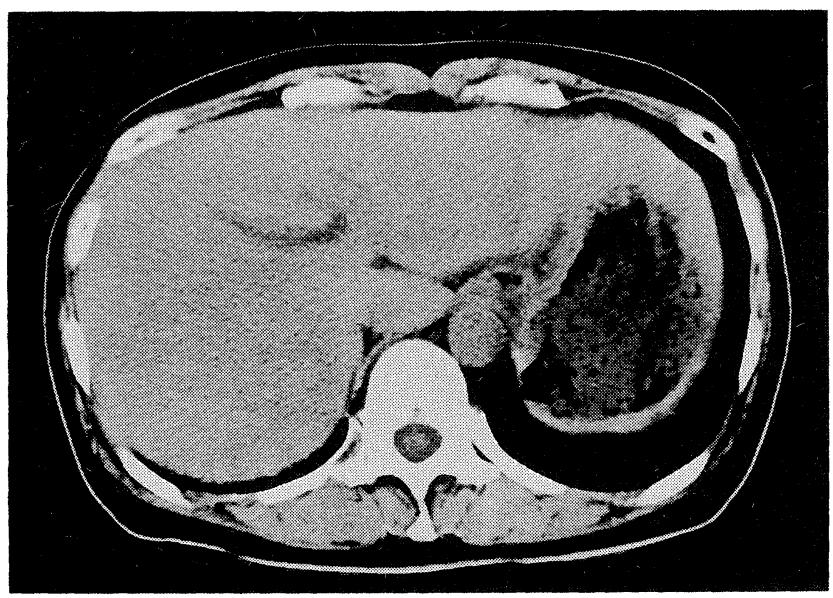

Figure 1. Abdominal CT demonstrated diffuse low density in the right lobe of the liver, which was compatible with the diagnosis of fatty liver.

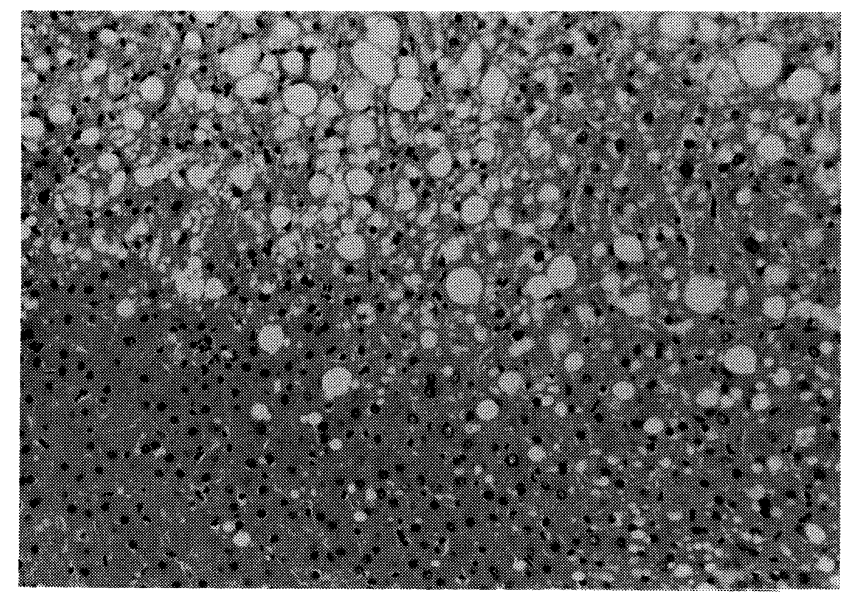

Figure 2. A microscopic examination of the liver showed steatosis. Over $70 \%$ of the liver cells contained small to medium sized fat vacuoles in the cytoplasm, but no fibrosis or inflammation was seen (HE stain, $\times 100$ ).

Table 1. Urea Cycle Enzyme Activities of the Biopsied Liver ${ }^{a}$

\begin{tabular}{llll}
\hline & Patient & Donor & Controls \\
\hline Carbamylphosphate synthetase & 0.033 & 0.026 & $0.036 \pm 0.013^{\mathrm{b}}$ \\
Ornithine transcarbamylase & 0.84 & 0.58 & $0.88 \pm 0.35$ \\
Argininosuccinate synthetase & 0.0023 & 0.020 & $0.033 \pm 0.012$ \\
Argininosuccinate lyase & 0.101 & 0.060 & $0.052 \pm 0.025$ \\
Arginase & 11.1 & 13.9 & $15.8 \pm 3.1$ \\
\hline
\end{tabular}

${ }^{a}$ Enzyme activities are expressed in $\mathrm{U} / \mathrm{mg}$ protein. ${ }^{\mathrm{b}}$ Values are expressed as mean $\pm \mathrm{SD}$. 


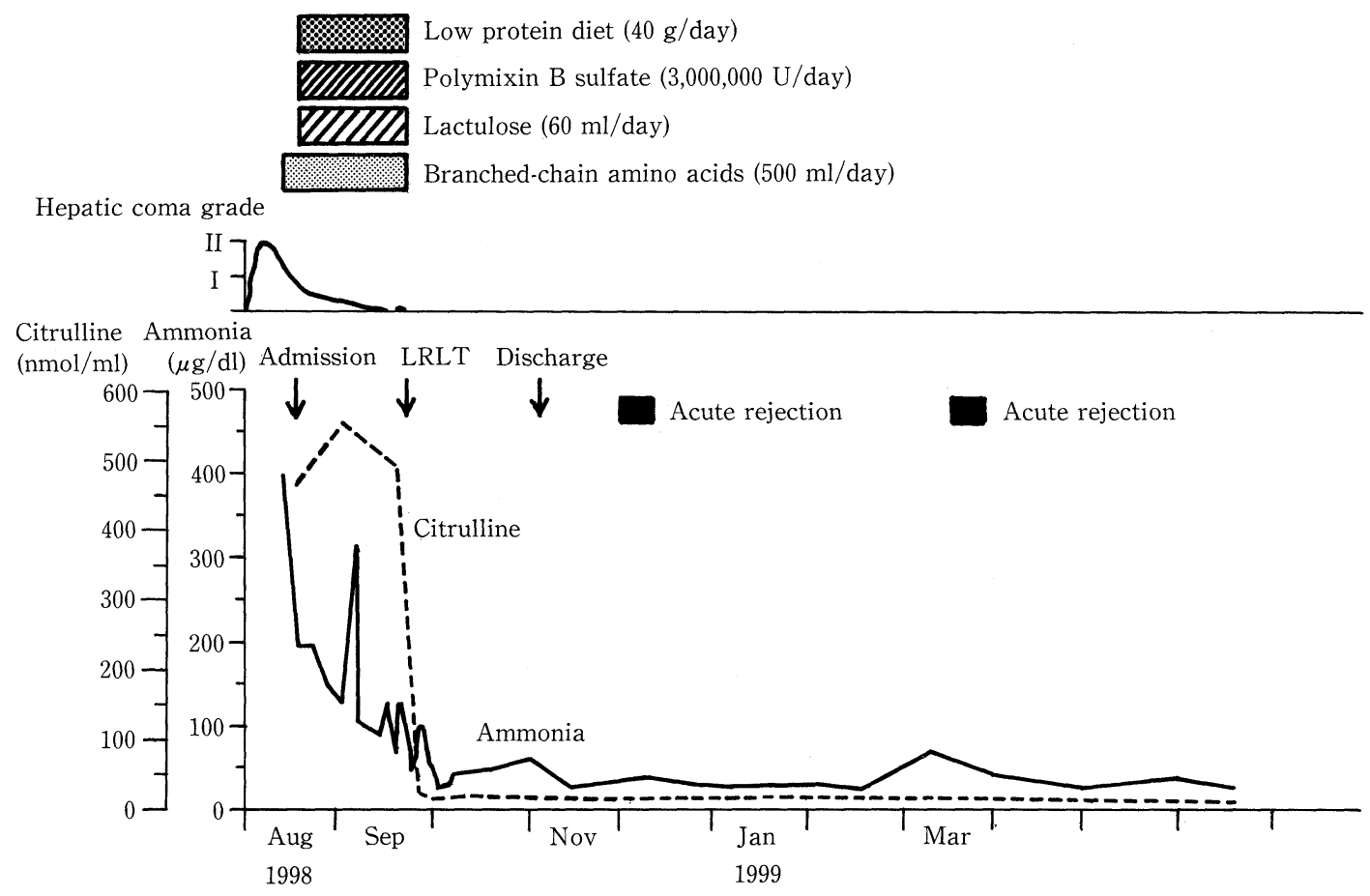

Figure 3. Clinical course of the patient. Plasma levels of ammonia and citrulline were normalized immediately after LRLT, and her neurological symptoms disappeared. The patient was discharged from the hospital on the 46th day after transplantation. During the 10-month follow-up, her condition was fairly good, though she was admitted twice for several days each due to mild acute rejection in the 3rd and 6th months.

\section{Discussion}

Type II adult-onset citrullinemia is caused by selective deficiency of ASS in the liver. ASS is the rate-limiting enzyme of the urea cycle and catalyses the formation of argininosuccinate from citrulline. Much like hepatic encephalopathy, ASS deficiency induces hyperammonemia and consciousness disturbance. The onset of adult-onset citrullinemia is characterized by the sudden appearance of such symptoms as disorientation, restlessness, drowsiness, and abnormal behavior. Generally, however, no characteristic abnormalities other than hyperammonemia are found in routine blood biochemical tests or imaging. The histological findings of the liver vary from normal tissue to fatty change, chronic hepatitis, or cirrhosis (4). Thus, in cases in which the liver is normal in appearance, hyperammonemia may be the sole clue to the presence of this disease.

Citrullinemia is diagnosed by a high concentration of plasma citrulline, a slight increase in plasma arginine, and deficiency of ASS activity in the liver tissue. The majority of previously reported cases of type II citrullinemia have involved Japanese patients (5-43). A MEDLINE search of all pertinent articles, including those written in Japanese, yielded 42 cases of type II citrullinemia (including the present case) (Table 2). The female: male ratio among these cases was 9:33. The mean age of onset was 34.7 years. The present patient is the oldest among these 42 cases. It remains to be elucidated why the clinical symptoms do not appear until adulthood, when the abnormality of ASS is thought to be genetically inherited and the levels of ASS are not thought to change with age. Since the level of hepatic ASS activity at the onset varies from case to case, there would seem to be no correlation between this level and the prognosis (4).

Once it appears, the encephalopathy generally follows a rapid and progressive course. Thus, fifteen of the twenty-one reported fatalities died within two years of onset. Previously, various conservative therapies have been tried, such as a low protein $\operatorname{diet}(5,6,10-14,16,18,19,22-24,30,32,33,35,36,38,39)$, dietary arginine supplementation $(5,7,9,10,13,19,23,36)$, sodium citrate $(12,16,19,21,22)$ or sodium benzoate administration $(7,13,18,19,21,25,30,33,38)$, lactulose administration $(6,10,11,13,16,18,19,22,25,35,36,38,39,41)$, non-absorbed antimicrobial agent administration $(6,13,18,39)$, and branched-chain amino acid infusion $(10,11,22,25,26$, $30-33,35,38,39,41)$. Peritoneal dialysis $(9,18,41)$ or hemodialysis $(15,29)$ has also been performed in several patients. However, although some of these treatments have contributed to a temporary alleviation of hyperammonemia and consciousness disturbance, they have failed to satisfactorily improve the long-term prognosis. The encephalopathy progresses rapidly, and is followed by decerebral state and deep coma. Most of 
TAKENAKA et al

Table 2. Reported Cases with Type II Citrullinemia

\begin{tabular}{|c|c|c|c|c|c|c|}
\hline & Author ${ }^{a}$ & Year & Age & Sex & Treatment $^{\mathrm{b}}$ & Outcome (period after onset) \\
\hline 1 & Hara (6) & 1981 & 28 & $\mathbf{M}$ & conservative & alive ( 2 month) \\
\hline 2 & Yamanaka (7) & 1984 & 28 & $\mathrm{~F}$ & conservative & alive (9 month) \\
\hline 3 & Itakura (8) & 1984 & 22 & $\mathbf{M}$ & conservative & death (9 year) \\
\hline 4 & Konishi (9) & 1984 & 14 & $\mathrm{~F}$ & peritoneal dialysis & death (9 month) \\
\hline 5 & Ohrui (10) & 1984 & 25 & $\mathbf{M}$ & conservative & death (4 year) \\
\hline 6 & Tobo (5) & 1985 & 22 & $\mathbf{M}$ & conservative & alive (6 month) \\
\hline 7 & Ohta (11) & 1985 & 24 & $\mathbf{M}$ & conservative & alive ( 8 month) \\
\hline 8 & Satomi (12) & 1986 & 32 & $\mathbf{M}$ & conservative & alive ( 8 month) \\
\hline 9 & Kodama (13) & 1986 & 24 & $\mathbf{M}$ & conservative & alive (16 month) \\
\hline 10 & Kodama (13) & 1986 & 43 & $\mathrm{~F}$ & conservative & alive ( 7 month) \\
\hline 11 & Shoda (14) & 1986 & 21 & $\mathbf{M}$ & conservative & death (17 month) \\
\hline 12 & Yamamoto (15) & 1986 & 46 & $\mathbf{M}$ & hemodialysis & death ( 3 year) \\
\hline 13 & Ikeda (16) & 1987 & 35 & $\mathbf{M}$ & conservative & death (16 month) \\
\hline 14 & Akiyama (17) & 1988 & 48 & $\mathbf{M}$ & conservative & alive (15 month) \\
\hline 15 & Kitai (18) & 1989 & 47 & $\mathbf{M}$ & peritoneal dialysis & alive (12 month) \\
\hline 16 & Ujihira (19) & 1989 & 44 & $\mathbf{M}$ & conservative & death (6 month) \\
\hline 17 & Muneoka (34) & 1989 & 21 & $\mathbf{M}$ & conservative & death (16 month) \\
\hline 18 & Mutoh (20) & 1990 & 48 & $\mathbf{M}$ & conservative & death (45 month) \\
\hline 19 & Itoh (21) & 1991 & 43 & $\mathbf{M}$ & conservative & death (11 month) \\
\hline 20 & Yuki (22) & 1991 & 29 & $\mathbf{M}$ & conservative & death (8 month) \\
\hline 21 & Arimura (23) & 1991 & 26 & $\mathbf{M}$ & conservative & death (8 year) \\
\hline 22 & Watanabe (24) & 1991 & 28 & $\mathbf{M}$ & conservative & death (5 year) \\
\hline 23 & Wada (25) & 1991 & 43 & $\mathbf{M}$ & conservative & death (24 month) \\
\hline 24 & Shindo (26) & 1991 & 24 & $\mathbf{M}$ & conservative & death (15 day) \\
\hline 25 & Todo (27) & 1992 & 35 & $\mathbf{M}$ & OLT & OLT (11 month) \\
\hline 26 & Tsuda (28) & 1992 & 27 & $\mathbf{M}$ & conservative & death ( 3 day) \\
\hline 27 & Ishii (29) & 1992 & 41 & $\mathbf{M}$ & hemodialysis & death (4 month) \\
\hline 28 & Tatsumoto (30) & 1992 & 34 & $\mathrm{~F}$ & conservative & death (14 month) \\
\hline 29 & Shiohama (31) & 1993 & 19 & $\mathbf{M}$ & conservative & alive ( 5 month) \\
\hline 30 & Saegusa (33) & 1993 & 29 & $\mathbf{M}$ & conservative & death (16 month) \\
\hline 31 & Saegusa (33) & 1993 & 59 & $\mathrm{~F}$ & conservative & alive ( 2 month) \\
\hline 32 & Tamakawa (32) & 1994 & 52 & $\mathrm{~F}$ & conservative & alive (1 year) \\
\hline 33 & Kawase (35) & 1995 & 31 & $\mathrm{~F}$ & conservative & death (16 month) \\
\hline 34 & Ohta (36) & 1996 & 27 & $\mathrm{~F}$ & conservative & alive (32 month) \\
\hline 35 & Yazaki (37) & 1996 & 25 & M & LRLT & LRLT (6 month) \\
\hline 36 & Hanazawa (38) & 1996 & 29 & $\mathbf{M}$ & conservative & alive (12 month) \\
\hline 37 & Suenaga (39) & 1997 & 46 & M & conservative & alive (1 month) \\
\hline 38 & Kawamoto (40) & 1997 & 39 & $\mathbf{M}$ & OLT & OLT (9 month) \\
\hline 39 & Kawamoto (40) & 1997 & 30 & $\mathbf{M}$ & conservative & death (10 month) \\
\hline 40 & Ogawa (41) & 1998 & 57 & M & peritoneal dialysis & alive ( 2 year) \\
\hline 41 & Yabe (43) & 1998 & 52 & $\mathbf{M}$ & APOLT & alive \\
\hline 42 & Our case & 1999 & 60 & $\mathrm{~F}$ & LRLT & LRLT (4 month) \\
\hline
\end{tabular}

${ }^{a}$ Number in parenthesis indicates the reference number. ${ }^{b}$ Conservative treatments include a low protein diet, dietary arginine supplementation, sodium citrate or sodium benzoate administration, lactulose administration, non-absorbed antimicrobial agent, hypertonic glucose infusion, and branched-chain amino acid infusion. OLT: orthotopic liver transplantation from cadaveric donors, LRLT: living related partial liver transplantation, APOLT: auxiliary partial orthotopic liver transplantation from living donors.

those patients who do not receive liver transplantation die within a few years. Even if a patient survives longer, severe organic brain damage cannot be avoided.

Two patients have previously been treated with orthotopic liver transplantation from cadaveric donors. The first case was performed in the United States by Todo et al in 1992 (27), and the other in Australia by Kawamoto et al in 1997 (40). The operations resulted in a successful course for both patients. The goal of the treatment of this disease is to correct the metabolic abnormality in the patient before irreversible brain damage occurs. Liver transplantation is a useful option for achieving this purpose, since the initial metabolic disturbance of this dis- 


\section{Liver Transplantation for Type II Citrullinemia}

ease is localized in the liver. It is possible that liver transplantation in the early stage of the disease prevents development of organic lesions in the brain due to the metabolic abnormalities.

Recently, various metabolic liver diseases have been treated with liver transplantation. In the United States, $5.3 \%$ of liver transplants are applied to metabolic disease (44). But liver transplantations from cadaveric donors have only just begun to be used in Japan, and may not be used widely for some time yet. On the other hand, the first successful case of LRLT was reported by Strong et al in 1990 (45), and was followed by a successful series of LRLTs by Broelsch et al in 1991 (46). In these reports, the LRLT was limited to infants, but its use has steadily increased, and accumulated experiences have extended its indication to adult patients $(47,48)$. Kawasaki et al (48) reported 13 cases of adult-to-adult LRLT. The liver replacement was successful in all of their patients, and none of them developed liver failure after surgery. While 2 patients with familial amyloid polyneuropathy died due to, respectively, Aspergillus pneumonia 2.5 months after transplantation and cerebral embolism 22 months after transplantation, the remaining 11 were reported to be well 2 to 35 months after LRLT. The postoperative course for each of the 13 donors was also uneventful and without significant complication.

For type II citrullinemia, the first patient treated successfully with LRLT was reported by Yazaki et al in 1996 (37). Since the causative genetic disorder of type II citrullinemia has now been elucidated (49), the introduction of a functional complementary DNA into hepatocyte by virus-mediated transfer may be a useful therapeutic option in the near future. In fact, hepatocyte gene therapy was reported to be successful in a neonatal bovine model of citrullinemia (50). However, until the clinical application of this modality, the use of liver transplantation -or in Japan, the use of LRLT in particular- would seem to be the only useful therapeutic approach for this disorder.

Although in a standard LRLT the whole liver is removed from the recipient, an auxiliary partial orthotopic liver transplantation (APOLT) has also recently been applied to a patient with type II citrullinemia (43). APOLT may have advantages over standard orthotopic liver transplantation in cases of a small for size graft, because the remnant native liver can support insufficient graft function until the graft has regenerated sufficiently. Moreover, in patients with non-cirrhotic metabolic liver disease, future gene therapy may still be possible in the preserved native liver. On the other hand, one notable drawback to APOLT is that the portal vein to the native liver must be ligated to prevent portal blood steal and to obtain optimal blood flow to the donor liver (43).

Because the causative disorder is hereditary and the liver graft is generally offered by one of the patient's relatives, as in the present case, we must confirm whether or not the donor has the same disorder, even if there are no symptoms. This is particularly necessary in cases of type II citrullinemia, which is likely to be an autosomal recessive disease $(2,4)$. The present donor, who was a son of the patient, was at least a heterozygous gene carrier and thus might have been an asymptomatic patient with type II citrullinemia. Measurement of his ASS activity was therefore necessary. We performed a liver biopsy from the donor, and confirmed that his ASS activity was normal before the operation.

In conclusion, here we reported a case of a 60 -year-old woman with type II citrullinemia that was successfully treated with LRLT. At present, LRLT is considered to be a useful and practical option that can fundamentally ameliorate this disorder.

Acknowledgements: We thank Dr. M. Makuuchi of the Second Department of Surgery, University of Tokyo, for his assistance with the LRLT, and Dr. K. Kobayashi of the Department of Biochemistry, Kagoshima University, for analysis of the ASS activity.

\section{References}

1) Saheki T, Ueda A, Hosoya M, et al. Qualitative and quantitative abnormalities of argininosuccinate synthetase in citrullinemia. Clin Chim Acta 109: 325-335, 1981.

2) Kobayashi K, Shaheen N, Kumashiro R, et al. A search for the primary abnormality in adult-onset type II citrullinemia. Am J Hum Genet 53: 1024-1030, 1993.

3) Kobayashi K, Horiuchi M, Saheki T. Pancreatic secretory trypsin inhibitor as a diagnostic marker for adult-onset type II citrullinemia. Hepatology 25: 1160-1165, 1997.

4) Yagi Y, Saheki T, Imamura $Y$, et al. The heterogeneous distribution of argininosuccinate synthetase in the liver of type II citrullinemic patients. Am J Clin Pathol 89: 735-741, 1988.

5) Tobo M, Naganuma H, Fujii I, Miya S, Saheki T. A sibling case of adulttype citrullinemia. Shinkei Naika (Neurological Medicine) 22: 81-84, 1985 (in Japanese).

6) Hara T, Tabira T, Shibasaki H, Kuroiwa Y, Saheki T. Hepatocerebral disease in a young adult with hypercitrullinemia and partial deficiency of liver argininosuccinate synthetase. Rinsyou Sinkeigaku (Clin Neurol) 21: 879-884, 1981 (in Japanese, Abstract in English).

7) Yamanaka M, Satou N, Inoue T, Satou I, Takayanagi M. A female case of adult-type citrullinemia with a psychiatric diagnosis of mania. Rinsyou Seishinigaku (Clin Neurol) 13: 433-442, 1984 (in Japanese, Abstract in English).

8) Itakura Y, Oyanagi K, Tsuchiyama A, Nakao T, Saheki T, Yagi Y. Localization of argininosuccinate synthetase in the liver of adult type citrullinemia complicated with hepatoma. Igaku No Ayumi (Journal of Clinical and Experimental Medicine) 130: 733-734, 1984 (in Japanese).

9) Konishi H, Yamaoka K, Matsuoka I, et al. A case of hepatocerebral disease with hypercitrullinemia which was diagnosed as hysteria. Seishin Igaku (Clinical Psychiatry) 26: 1219-1223, 1984 (in Japanese).

10) Ohrui M, Kawano M, Sugita T, et al. A case of adult-type citrullinemia. Nippon Shokakibyo Gakkai Zasshi (Jpn J Gastroenterol) 81: 1853-1857, 1984 (in Japanese).

11) Ohta S, Takahashi $Y$, Yashima $Y$, et al. Serial EEG study on a case of hypercitrullinemia presenting as consciousness disturbance. Rinsyou Noha (Clinical Electroencephalography) 27: 609-611, 1985 (in Japanese).

12) Satomi A, Takada $Y$, Ishida $K$, Shimizu $H$, Sakazumi $Y$, Ishii J. A case of adult-type citrullinemia with a polyp of the gall bladder. Nippon Rinsyou Geka Igakkai Zasshi (Journal of Japanese Society for Clinical Surgery) 47: 477-480, 1986 (in Japanese, Abstract in English).

13) Kodama K, Yamauchi N, Okada S, Sakamoto T, Yamanaka M. Adult hypercitrullinemia. Rinsyou Seishin Igaku (Japanese Journal of Clinical Psychiatry) 15: 1233-1235, 1986 (in Japanese).

14) Shoda T, Ochi M, Murase M, et al. Changes in the electroencephalogram, cerebral visual evoked potential and plasma NH3 levels in adult-type citrullinemia. Rinsyou Byori (The Japanese Journal of Clinical Pathology) 34: 1213-1218, 1986 (in Japanese). 
15) Yamamoto S, Hıno K, Ohumi K, et al. An autopsy case of adult-type citrullinemia accompanied with cerebral bleeding. Naika (Internal Medicine) 58: 881-883, 1986 (in Japanese).

16) Ikeda M, Orimo $S$, Kurosawa $T$, Arai M, Hiyamuta E. A case of citrullinemia with cluster type distribution of argininosuccinate synthetase in the liver. Rinsyo Shinkeigaku (Clin Neurol) 27: 931-935, 1987 (in Japanese, Abstract in English).

17) Akiyama K, Hasegawa T, Ogasawara M, et al. A case of adult-type citrullinemia. Nippon Naika Gakkai Zasshi (The Journal of the Japanese Society of Internal Medicine) 77: 510-515, 1988 (in Japanese).

18) Kitai K, Yamashita Y, Iuchi H, Kimura $Y$, Ichikawa $M$, Kondo T. Usefulness of continuous peritoneal dialysis (CPD) for the management of metabolic encephalopathy in adult type citrullinemia. Nippon Shokakibyo Gakkai Zasshi (Jpn J Gastroenterol) 86: 2469-2473, 1989 (in Japanese).

19) Ujihira $N$, Ohya $M$, Mabuchi $C$, Indo $T$, Hashizume $Y$. An autopsied case of type II citrullinemia - transient effectiveness with either citrate or benzoate to consciousness disturbance. Rinsyo Shinkeigaku (Clin Neurol) 29: 436-441, 1989 (in Japanese, Abstract in English).

20) Mutoh F, Miyagishi T. Serial EEG study on a case of adult-type citrullinemia. Rinsyo Nouha (Clinical Electroencephalography) 32: 754759, 1990 (in Japanese).

21) Itoh N, Muramatsu K, Mori S, et al. An autopsy case of hepatocerebral disease due to argininosuccinate synthetase deficiency. Seishin Igaku (Clinical Psychiatry) 33: 511-519, 1991 (in Japanese).

22) Yuki N, Kaneko K, Yanagisawa K, Ohno T, Miyatake T. The correlation of consciousness level and the concentration of CSF ammonia in a patient with adult-type citrullinemia. Rinsyo Shinkeigaku (Clin Neurol) 31: 765-767, 1991 (in Japanese, Abstract in English).

23) Arimura A, Azegami N, Yoshimura H, Arita M, Kamisaka K, Maezawa H. An autopsied case of adult type citrullinemia complicated with large hepatocellular carcinoma. Kanzou (Acta Hepatologica Japonica) 32: 793797, 1991 (in Japanese, Abstract in English).

24) Watanabe $S$, Takeda I, Ohkuma $S$, et al. An adult type citrullinemia with chronic hepatitis type B who died from hepatoma in a short term with paraneoplastic syndrome. Kanzou (Acta Hepatologica Japonica) 32: 295299, 1991 (in Japanese, Abstract in English).

25) Wada S, Matsuo K, Nozawa K, et al. A case of citrullinemia with fair response to oral administration of sodium benzoate for consciousness disturbance. Nippon Shokakibyo Gakkai Zasshi (Jpn J Gastroenterol) 88: 2166-2170, 1991 (in Japanese).

26) Shindo K, Tsunoda S, Shiozawa $Z$. Adverse effects of branched chain amino acid transfusion on type II citrullinemia - report of an adult case. Rinsyo Shinkeigaku (Clin Neurol) 31: 407-411, 1991 (in Japanese, Abstract in English).

27) Todo S, Starzl TE, Tzakis A, et al. Orthotopic liver transplantation for urea cycle enzyme deficiency. Hepatology 15: 419-422, 1992.

28) Tsuda M, Miyazaki M, Tanaka Y, Kuzuhara S, Sirabe T. An autopsy case of adult type citrullinemia. Naika (Internal Medicine) 69: 359-360, 1992 (in Japanese).

29) Ishi A, Ohkoshi $K$, Oka $H$, Ban $S$, Takahashi A. A case of citrullinemia associated with isolated ACTH deficiency rapidly developing coma. Rinsyou Sinkeigaku (Clin Neurol) 32: 853-858, 1992 (in Japanese).

30) Tatsumoto T, Yamamoto K, Kudo J, et al. An autopsy case of citrullinemia type II complicated with chronic pancreatitis. Fukuoka Igaku Zasshi 83: 43-50, 1992 (1n Japanese, Abstract in English).

31) Shiohama N, Sugita Y, Imamura N, Sato T, Mizuno Y. Type II citrullinemia triggered by acetaminophen. No To Shinkei (Brain and Nerve) 45: 865-
870. 1993 (in Japanese, Abstract in English).

32) Tamakawa S, Nakamura H, Katano T, Yoshizawa M, Ohtake K, Kubota $T$. Hyperalimentation therapy produces a comatose state in a patient with citrullinemia. Nippon Syuutyuuchiryou Igakkai Zasshi (J Jpn Soc Intensive Care Med) 1: 37-41, 1994 (in Japanese, Abstract in English).

33) Saegusa $S$, Sugaya $H$, Kobayashi $T$, et al. Laparoscopical findings of late onset hyper citrullinemia. Gastroenterol Endosc 35: 1616-1622, 1993 (in Japanese, Abstract in English).

34) Muneoka Y, Miyoshi N, Honma Y, Ohkouchi H, Kawamura K. A case of adult type citrullinemia. Shiritsu Kushirosougoubyouin Igaku Zasshi 1: 111-117, 1989 (in Japanese).

35) Kawase Y, Tanabashi S, Shiroko J, et al. A case of adult type citrullinemia combined with decreased carbamylphosphate synthetase activity. Kanzou (Acta Hepatologica Japonica) 36: 302-307, 1995 (in Japanese, Abstract in English).

36) Ohta N, Saito T, Hayashi Y, Sakai N, Saito H, Hiroi M. A case of citrullinemia repeatedly induced by pregnancy. Nippon Sanka Fujinka Gakkai Zasshi (Acta Obst Gynaec Jpn) 48: 351-354, 1996 (in Japanese).

37) Yazaki M, Ikeda S, Takei Y, et al. Complete neurological recovery of an adult patient with type II citrullinemia after living related partial liver transplantation. Transplantation 62: 1679-1681, 1996.

38) Hanazawa $H$, Hayashı R, Ikeda M, et al. A case of adult type citrullinemia suspected of influent intoxication delirium. Seishin Igaku (Clinical Psychiatry) 38: 1289-1292, 1996 (in Japanese).

39) Suenaga T, Morinaka K, Tsuboi K, Matsunaga N, Sakai S, Onoyama E. A case of adult citrullinemia. Shimane Igaku 17: 362-366, 1997 (in Japanese).

40) Kawamoto S, Strong RW, Kerlin P, et al. Orthotopic liver transplantation for adult-onset type II citrullinaemia. Clin Transplantation 11: 453-458, 1997.

41) Ogawa K, Takashima S, Hirade S, Futamura A, Ueno H, Inoue H. Adultonset type II citrullinemia in a patient undergoing continuous ambulatory peritoneal dialysis. Rinsyou Shinkeigaku (Clin Neurol) 38: 826-830, 1998.

42) Kawata A, Suda M, Tanabe H. Adult-onset type II citrullinemia: clinical pictures before and after liver transplantation. Intern Med 36: 408-412, 1997.

43) Yabe $\mathrm{S}$, Egawa $\mathrm{H}$, Inomata $\mathrm{Y}$, et al. Auxiliary partial orthotopic liver transplantation from living donors. Transplantation 66: 484-488, 1998

44) Kilpe VE, Krakauer H, Wren RE. An analysis of liver transplant experience from 37 transplant centers as reported to Medicare. Transplantation 56: 554-561, 1993.

45) Strong RW, Lynch SV, Ong TH, Matsunami H, Koido Y, Balderson GA. Successful liver transplantation from a living donor to her son. $\mathrm{N}$ Engl $\mathrm{J}$ Med 322: 1505-1507, 1990.

46) Broelsch CE, Whitington PF, Emond JC, et al. Liver transplantation in children from living related donors. Ann Surg 214: 428-439, 1991.

47) Hashikura $Y$, Makuuchi $M$, Kawasaki $S$, et al. Successful living related partial liver transplantation to an adult patient. Lancet 343: 1233-1234, 1994 (letter).

48) Kawasaki S, Makuuchi M, Matsunami H, et al. Living related liver transplantation in adults. Ann Surg 227: 269-274, 1998.

49) Kobayashi K, Sinasac DS, Iijima M, et al. The gene mutated in adultonset type II citrullinaemia encodes a putative mitochondrial carrier protein. Nat Genet 22: 159-163, 1999.

50) Lee B, Dennis JA, Healy PJ, et al. Hepatocyte gene therapy in a large animal: A neonatal bovine model of citrullinemia. Proc Natl Acad Sci USA 96: 3981-3986, 1999. 